\title{
ANALYZING İSTANBUL COASTLINE CHANGES DUE TO LEGAL ARRANGEMENTS BETWEEN 1852 AND 2011
}

\author{
NAZİFE TUĞÇE ONUK ${ }^{1} \&$ AZIME TEZER ${ }^{2}$ \\ ${ }^{1}$ Landscape Architecture Department, Architecture Faculty, İstanbul Technical University, Turkey \\ ${ }^{2}$ Regional Planning Department, Architecture Faculty, İstanbul Technical University, Turkey
}

\begin{abstract}
İstanbul, as one of the most significant coastal cities of Turkey, has very unique cultural, historical, ecological and social dynamics. As the economic centre of the country, the city has been exposed to human attraction throughout centuries. However, in recent decades Istanbul has been experiencing rapid growths in population; this has instigated dramatic changes regarding the urban patterns, as well as the coastline of the city. Although some legal regulations had been arranged as a precaution to protect the uniqueness of the city's coastal areas, these efforts of conserving the coastline have been overruled by unforeseen planning actions, which resulted in more deformation in the last decades. In this paper, we aim to determine the coastline changes in İstanbul between 1852 and 2011 and unravel their correlation with the legal regulations implemented. As evidence for this argument, we will utilise historical maps and aerial photographs, these resources will be assessed with GIS overlapping technique to identify the differences in coastal lines. The coastlines in these zones have been grouped as 'natural, deformed or artificial' according to its physical characteristics. As a result, visuals are compared to show the change in the coastline's characteristics, and the relation of these changes to regulations will be discussed in each analysed year. The findings are expected to be used for further research on the assessment of lost or degraded change in coastal lines between 1852 and 2011.
\end{abstract}

Keywords: coastal policy, coastline change, Moltke Map, Necip Bey Map, GIS, Istanbul.

\section{INTRODUCTION}

Coastal ecosystems, where approximately $40 \%$ of the world's population lives, provide a much more viable habitat in comparison to other ecosystems; they are also the most productive, and in exchange of human consumption are the most endangered ecosystem type. Turkey has a total of $8333 \mathrm{~km}$ of coastline on its mainland, and $1607 \mathrm{~km}$ in islands [1]. Since Ottoman times, İstanbul coastline has undergone significant changes in order to support the increasing population's requirements and political reasons. Studies have shown that from 1987 to 2011, the occupied area in İstanbul's coastline increased to $60 \mathrm{~km}$ [2].

It is presumed that one of the reasons for this significant change might be the legislations and laws applied for the coastal planning and management. Istanbul, has grown in size, proportionally to the rapid urbanization correlated with the Industrialization in Turkey after 1950 s, and has reached its current urban structure after the migration waves of the 1970s and 1990s [3], [4]. According to the population increase, the urban development has advanced to the east-west axis of the Marmara Sea coastline and on both sides of the northern region of the Bosphorus with the effect of the second bridge and its included infrastructure, such as connection roads [5].

Before 1972 coastal issues were managed only by implementing the Civil Law's 641st Article, but the natural statue of the coastlines, coastal planning problems, urbanization problems, coastal tourism etc. are examples of topics that were not included in these legal regulations. With the 7-8 supplementary items of 6785 Construction Law, which were added as a response to the Human and Environment Conference held in Stockholm, 1972, are the first legal regulations on structure construction management on coastal areas. However, they only applied within the first $10 \mathrm{~m}^{2}$ of the coastline and the legislation did not include 
definitions such as coastline usage [6]. Our current era privatization of the coastal fill area has become widespread, land speculation on areas behind the coastal line has gained momentum [6]. With the 1982 Constitution, considerations on public interest in coastal planning had been introduced and alongside the 1983 Bosphorus Law; the cultural, historical and natural structures have been preserved by the prohibition of construction practices on the Bosphorus coastline and Bosphorus front view areas, as well as demolishing the illegal structures. But during the times of coup in early 1980s, Tourism Promotion Law and Bosphorus Law had resurfaced and once again allowed construction on the Bosphorus front view area and its periphery, which consequently resulted in the coastal areas to once again become targets of the land speculators. Since 1984, an increase in urbanization on the coastal line had been observed in causation to Coastline Law's No. 3086 allowing sea, lake and river filling and drying processes for public interest, while letting construction in the areas without public priority [6]. With the number/segment/unit 3621 Coastline Law, it has been ruled that the coastlines should be preserved and the natural/cultural structure of the Coastlines should be planned in consonance to public interest - this means that the coastline should be open to public use.

Construction circumstances were redefined in 1992 with the introduction of Law No. 3830. It had been decided that the structure planning on the coastal line should be at least $50 \mathrm{~m}$ inland from the coastline as a requirement [6]. In 2005, with the supplementary item $5398 / 13$ of Coastline Law No. 3621, it has been allowed to construct yacht and cruiser harbours in coastal lands or fill areas. The spatial evaluation of the effects of the Coast Law and legislations on the coastlines has been summarized in Table 1.

Within this article, we aim to clarify the relationship between the transformation in İstanbul's coastal line between 1852 and 2011 and the legislative developments in the given timeframe. Also, to demonstrate the alteration on the Coastal Lines of İstanbul, which is under pressure because of urbanization, for the last 161 years.

\section{MATERIAL AND METHOD}

This research aims to observe the stages of the transformations on the İstanbul coastline, within approximately 20-year periods, between 1852 and 2011. To observe these shifts we will study historical maps (1852 Moltke Map, 1918 Necip Bey Map) and aerial photographs $(1946,1966,1982,2011)$ and these resources will be analysed using a GIS overlapping technique. Since historical maps generally have different border lines and their production methods were very definitive, and due to these differences in producing imagery, minor mismatches will be present; hence, some of the maps and aerial photographs cannot be completely overlapped. Thus, available data borders and map drawings have been divided into 7 different zones according to common features present in both the maps and the satellite imaging. All zones have been studied separately to reassure the validity of the results. The coastlines in these zones have been categorized as 'natural, deformed or artificial' according to its physical characteristics. As a result, images are compared to depict the metamorphosis in coastline character and after discussed through regulations in each analysed year.

\section{ANALYZING ISTANBUL COASTLINES}

The researched area has been determined according to the borders of the maps analysed between 1852 and 2011 and the related aerial photos. The borders for the research area shown in Fig. 1, on the north coastline of the Istanbul Bosphorus, where it meets with the Black Sea, (west-side border coordinates 28,950688; 41,200662 and east-side border coordinates $29,386370 ; 41,224694)$ and on the south coastline, where it meets with the Marmara Sea (west-side border coordinates 28,709966; 40952882 and east-side border coordinates $29,177031 ; 40,889988)$ 
Table 1: The effect of the law and legislations on the coastline usage since Ottoman Ages.

\begin{tabular}{|c|c|c|}
\hline \multirow{2}{*}{ 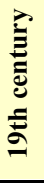 } & $\begin{array}{l}\bar{d} \\
\frac{\vec{J}}{D} \\
\approx \\
\approx\end{array}$ & Civil Law, article 641 \\
\hline & $\begin{array}{l}\underset{\mathrm{J}}{\tilde{g}} \\
\text { 近 } \\
\end{array}$ & Place-to-place usage as accommodation \\
\hline \multirow{2}{*}{ 䒘 } & 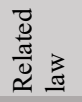 & 7-8 Supplementary items of Zoning Law No. 6785 \\
\hline & 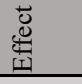 & Tourism - privatization through filling in coastal lines. \\
\hline \multirow{2}{*}{$\stackrel{0}{\mathscr{\sigma}}$} & 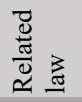 & 1982 constitution, article 43 \\
\hline & 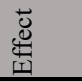 & Increase in public usage \\
\hline \multirow{2}{*}{$\stackrel{\mathscr{0}}{2}$} & 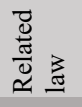 & Bosphorus Law \\
\hline & 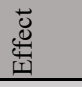 & Protection of Bosphorus Silhouette \\
\hline \multirow{2}{*}{ 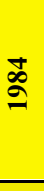 } & 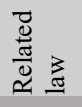 & Coast Law No. 3086 \\
\hline & 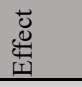 & Increase in building in Coastal lines \\
\hline \multirow[t]{2}{*}{ ڤั } & 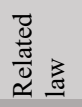 & Coastal Law No. 3621 \\
\hline & 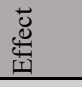 & Increase in public usage \\
\hline \multirow{2}{*}{ ڤ્) } & 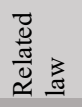 & Coastal Law No. 3621 of supplementary item 5398/13 \\
\hline & 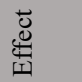 & Harbour-marina construction \\
\hline
\end{tabular}

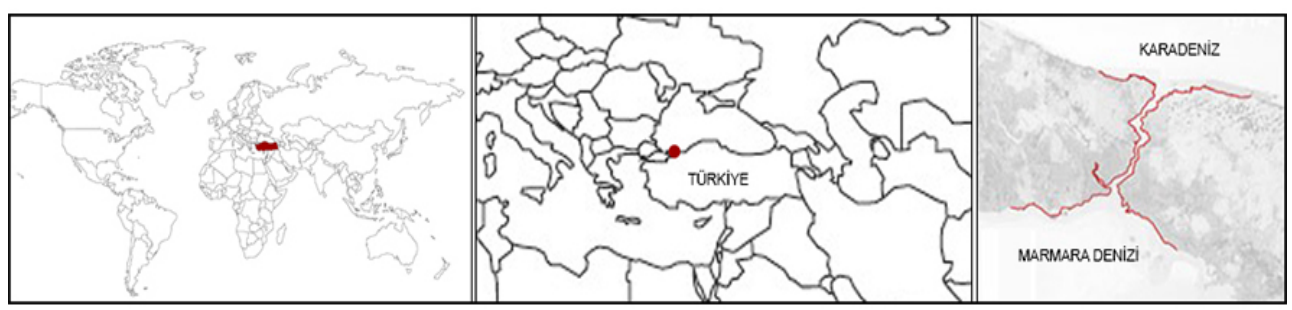

Figure 1: Research area location. 
In Fig. 2, seven different colours, representing 7 different zones, with their approximate length are shown. Every colour on the map has been coded with a letter referencing Zone names.

The zones, which were determined according to the aforementioned resources, have been analysed in 3 different classifications defined by coastline's current statues as natural, deformed or artificial. While analysing the zones, definitions have been assigned to the coastline types in accordance to the two situations as listed below:

1. Whether the observed coastline is original, as in the reference map or not (checked with older maps and aerial photos).

2. Verification of whether the land use of the inner coastal area has changed or not.

According to these verifications, the types of coastlines and their respective descriptions are:

- Natural coastline type, where there has been no change by artificial influence in the original statue of coastline.

- Deformed coastline type, where there has been no change on the coastline location(plan) due to filling or digging, but natural land character has been lost due to land use in inlands.

- Artificial coastline type, where the location and natural characteristic of the coastline is completely transformed.

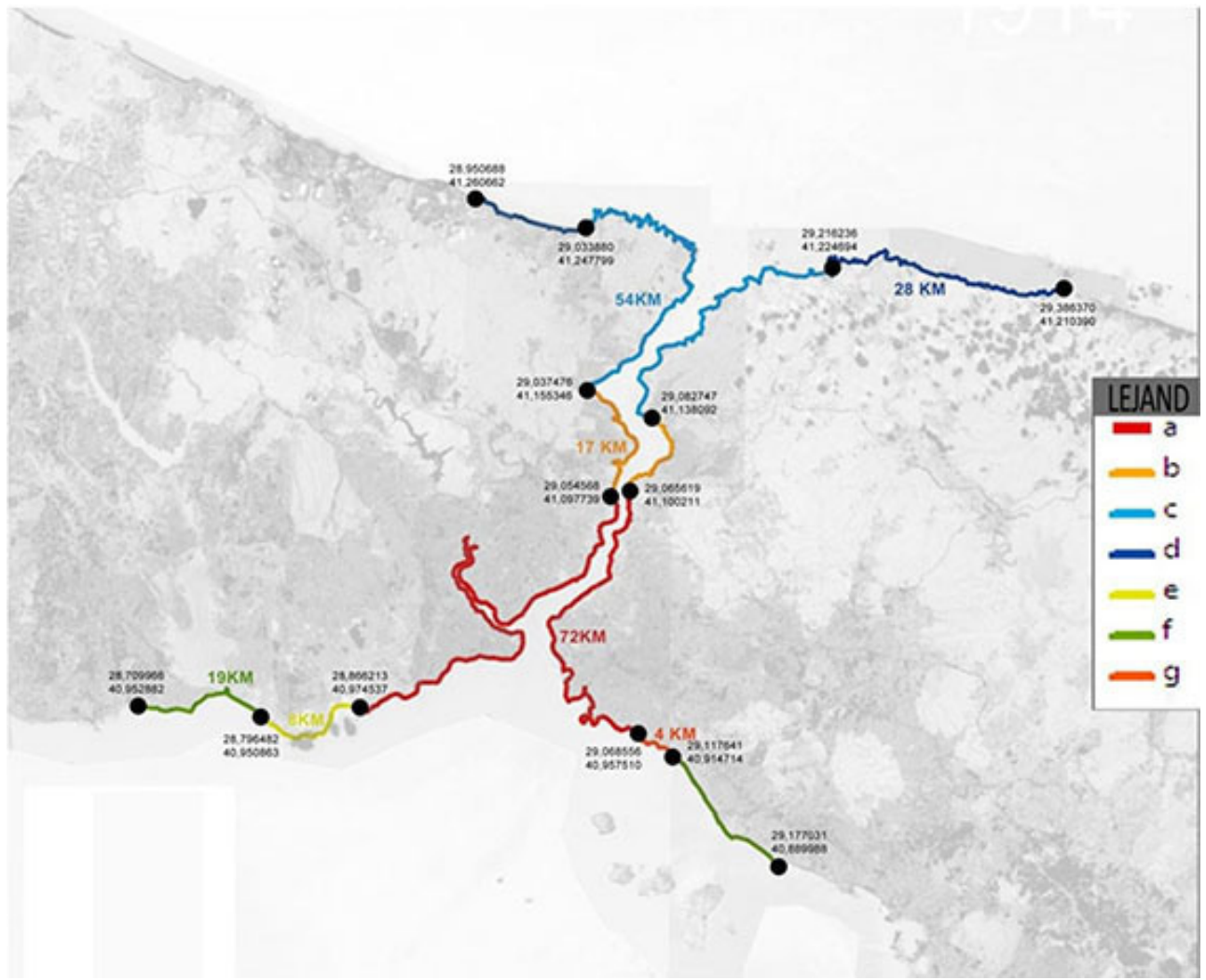

Figure 2: Map showing analysed zones. 
After analysing the coastline as natural, deformed and artificial, the percentage distribution of the coastline characters has been calculated and visualized as graphs showing the coastal character changes due to years.

The data calculated for these zones are as below:

Analysis of Zone A: The "A" zone, which is shown with red colour on the map, covers areas between Beşiktaş-Haliç-Bakırköy on west, and Göksu-Üsküdar-Erenköy on east. Total coastline length is $72371,6413 \mathrm{~m}$. The analysed data years are 1852, 1918, 1946, 1966, 1982, and 2011.

Graphical analysis: The natural coast line, which was $40 \%$ by 1852 and 1918 , is completely changed in 1946, and by 1966 it has been completely artificialized (Table 2 , Fig. 3(a)).

Analysis of Zone B: The "B" zone, which is shown with orange colour on the map, covers areas between Tarabya-Yeniköy-Emirgan on the west, and Beykoz on the east. Total coastline length is $169,426,206 \mathrm{~m}$. The analysed data years are 1918, 1946, 1966, 1982, and 2011.

Graphical analysis: The natural coastline, which was $50 \%$ by 1918 , has been $20 \%$ deformed with a rate of $20 \%$ by 1946 , and by 1966 it has been almost completely artificialized. It is clear that the natural coastline degradation rates have accelerated immensely between 1946 and 1966 (Table 3, Fig. 3(b)).

Table 2: Zone A coastline character distribution according to the year.

\begin{tabular}{|c|c|c|c|c|c|c|c|}
\hline \multirow{5}{*}{ 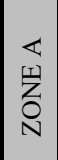 } & \multirow{2}{*}{$\begin{array}{l}\text { Coastline } \\
\text { character }\end{array}$} & \multicolumn{6}{|c|}{ Coastline length per year } \\
\hline & & 1852 & 1916 & 1946 & 1966 & 1982 & 2011 \\
\hline & Natural & $300,736,730$ & $290,937,155$ & $53,118,058$ & & & \\
\hline & Deformed & $395,950,230$ & $396,110,314$ & $291,799,906$ & $56,809,910$ & $20,915,346$ & $5,408,467$ \\
\hline & Artificial & $27,029,453$ & $36,668,944$ & $378,798,450$ & $666,906,503$ & $702,801,068$ & $718,307,946$ \\
\hline
\end{tabular}

Table 3: Zone B coastline character distribution according to the year.

\begin{tabular}{|c|c|c|c|c|c|c|c|}
\hline \multirow{5}{*}{\begin{tabular}{l}
$n$ \\
\multicolumn{1}{c}{} \\
Z \\
$\mathrm{N}$
\end{tabular}} & \multirow{2}{*}{$\begin{array}{l}\text { Coastline } \\
\text { Character }\end{array}$} & \multicolumn{6}{|c|}{ Coastline length per year } \\
\hline & & 1852 & 1916 & 1946 & 1966 & 1982 & 2011 \\
\hline & Natural & & $85,423,151$ & $54,679,879$ & $2,388,421$ & & \\
\hline & Deformed & & $84,003,055$ & $63,819,920$ & $2,682,054$ & $5,070,475$ & 989,374 \\
\hline & Artificial & & & $50,926,407$ & $164,355,730$ & $164,355,730$ & $168,436,832$ \\
\hline
\end{tabular}

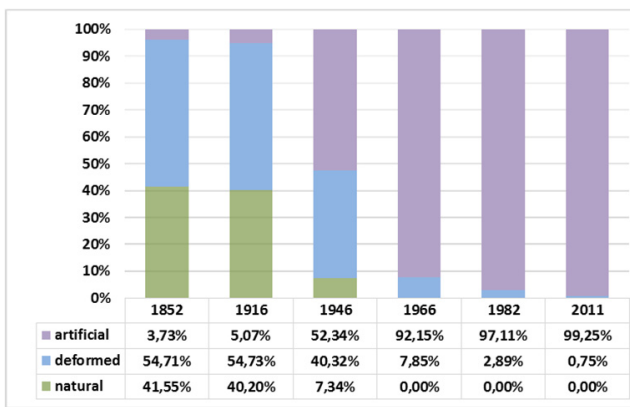

(a)

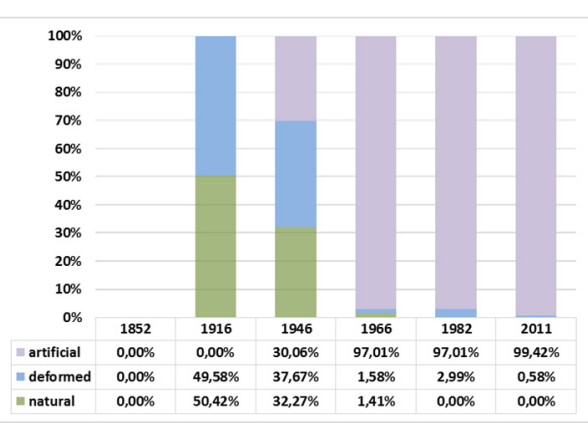

(b)

Figure 3: Coastline character distribution in (a) Zone A and (b) Zone B by years (\%). 
Analysis of Zone C: The "C" zone, which is shown with blue colour on the map, covers areas between Rumeli Feneri-Sariyer on the west, and Anadolu Feneri on the east. Total coastline length is 542,107,603 m. The analysed data years are 1918, 1946, 1982, and 2011.

Graphical analysis: Natural coastline loss is recorded as the fastest between 1982 and 2011 (Table 4, Fig. 4(a)).

Analysis of Zone D: The "D" zone, which is shown with dark blue colour on the map, covers areas between Kumköy-Kısırkaya on the west, and Riva on the east. Total coastline length is $281,696,876 \mathrm{~m}$. The analysed data years are 1918 and 2011.

Graphical analysis: Natural coastline, which was completely natural by 1918 , still mostly preserves its natural state in 2011 (Table 5, Fig. 4(b)).

Analysis of Zone E: The "E" zone, which is shown with yellow colour on the map, covers the Yeşilköy part of İstanbul. Total coastline length is $83,913,827 \mathrm{~m}$. The analysed data years are 1918, 1982 and 2011.

Graphical analysis: It can be seen that the coastline, which had no artificial parts and was $78.53 \%$ natural in 1918, has been $96.01 \%$ deformed (artificialization and deformation) and no natural coastline is left. The natural coastline loss has occurred between the years of 1918 and 1982, for which there is no data (Table 6, Fig. 5(a)).

Table 4: Zone $\mathrm{C}$ coastline character distribution according to the year.

\begin{tabular}{|c|c|c|c|c|c|c|c|}
\hline \multirow{5}{*}{ 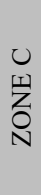 } & \multirow{2}{*}{$\begin{array}{l}\text { Coastline } \\
\text { Character }\end{array}$} & \multicolumn{6}{|c|}{ Coastline length per year } \\
\hline & & 1852 & 1916 & 1946 & 1966 & 1982 & 2011 \\
\hline & Natural & & $497,491,607$ & $461,146,835$ & & $444,584,933$ & $374,142,300$ \\
\hline & Deformed & & $44,615,996$ & $67,056,400$ & & $12,601,553$ & $63,997,399$ \\
\hline & Artificial & & & $13,904,368$ & & $84,921,117$ & $1,039,679,045$ \\
\hline
\end{tabular}

Table 5: Zone D coastline character distribution according to the year.

\begin{tabular}{|c|c|c|c|c|c|c|c|}
\hline \multirow{5}{*}{ 兄 } & \multirow{2}{*}{$\begin{array}{l}\text { Coastline } \\
\text { Character }\end{array}$} & \multicolumn{6}{|c|}{ Coastline length per year } \\
\hline & & 1852 & 1916 & 1946 & 1966 & 1982 & 2011 \\
\hline & Natural & & $281,696,876$ & & & & $276,507,647$ \\
\hline & Deformed & & & & & & $5,189,229$ \\
\hline & Artificial & & & & & & \\
\hline
\end{tabular}

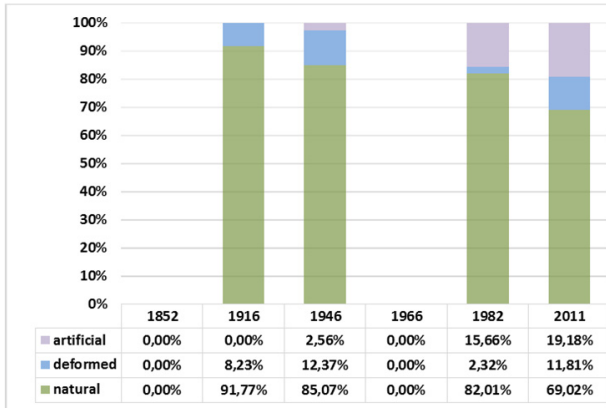

(a)

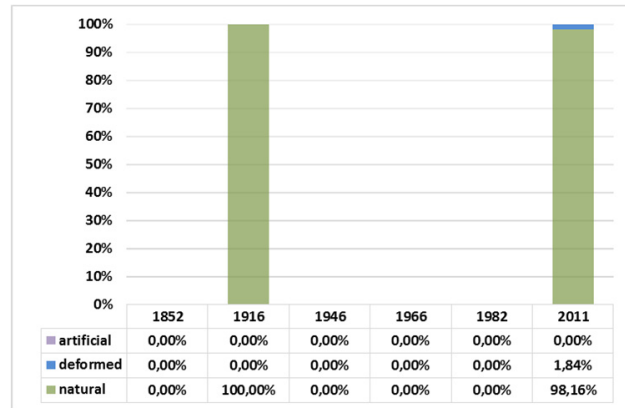

(b)

Figure 4: Coastline character distribution in (a) Zone C and (b) Zone D by year (\%). 
Analysis of Zone F: The "F" zone, which is shown with green colour on the map, covers Yeşilköy-Avcılar on the west and areas between Küçükyalı-Kartal on the east. Total coastline length is $185,862,645 \mathrm{~m}$. The analysed data years are 1982 and 2011.

Graphical analysis: No data can be found to be analysed until 1982. It had lost $97.44 \%$ of its natural coastline by then. $22.48 \%$ of deformed coastlines were also artificialized by 2011 (Table 7, Fig. 5(b)).

Analysis of Zone G: The "G" zone, which is shown with dark orange colour on the map, covers areas between Erenköy and Küçükyalı. Total coastline length is 39,635,968 m. The analysed data years are 1918, 1966, 1982, and 2011.

Graphical analysis: The Zone G, which had $100 \%$ natural coastline in 1916, has been 100\% artificialized by 1966 (Table 8, Fig. 6).

Table 6: Zone E coastline character distribution according to the year.

\begin{tabular}{|c|c|c|c|c|c|c|c|}
\hline \multirow{5}{*}{ 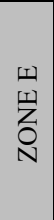 } & \multirow{2}{*}{\begin{tabular}{|l}
$\begin{array}{l}\text { Coastline } \\
\text { character }\end{array}$ \\
\end{tabular}} & \multicolumn{6}{|c|}{ Coastline length per year } \\
\hline & & 1852 & 1916 & 1946 & 1966 & 1982 & 2011 \\
\hline & \begin{tabular}{|l} 
Natural \\
\end{tabular} & & $65,900,418$ & & & $3,349,793$ & \\
\hline & Deformed & & $18,013,409$ & & & $33,414,005$ & $20,103,687$ \\
\hline & Artificial & & & & & $47,150,029$ & $63,810,140$ \\
\hline
\end{tabular}

Table 7: Zone F coastline character distribution according to the year.

\begin{tabular}{|c|c|c|c|c|c|c|c|}
\hline \multirow{5}{*}{$\begin{array}{l}\text { I } \\
\text { 崩 } \\
\text { ○ }\end{array}$} & \multirow{2}{*}{$\begin{array}{l}\text { Coastline } \\
\text { Character }\end{array}$} & \multicolumn{6}{|c|}{ Coastline length per year } \\
\hline & & 1852 & 1916 & 1946 & 1966 & 1982 & 2011 \\
\hline & Natural & & & & & $4,762,326$ & $5,331,071$ \\
\hline & Deformed & & & & & $72,096,653$ & $30,322,042$ \\
\hline & Artificial & & & & & $109,003,666$ & $150,209,532$ \\
\hline
\end{tabular}

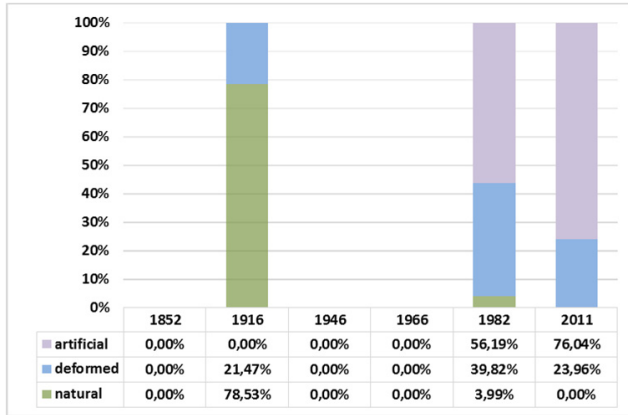

(a)

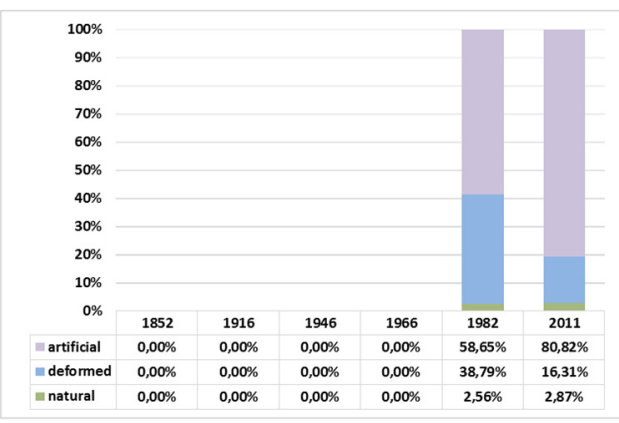

(b)

Figure 5: Coastline character distribution in (a) Zone E and (b) Zone F by year (\%). 
Table 8: Zone G coastline character distribution according to the year.

\begin{tabular}{|c|c|c|c|c|c|c|c|}
\hline \multirow{5}{*}{\begin{tabular}{c}
0 \\
\multicolumn{1}{|c}{} \\
$\stackrel{0}{0}$
\end{tabular}} & \multirow{2}{*}{$\begin{array}{l}\text { Coastline } \\
\text { Character }\end{array}$} & \multicolumn{6}{|c|}{ Coastline length due to years } \\
\hline & & 1852 & 1916 & 1946 & 1966 & 1982 & 2011 \\
\hline & Natural & & $38,635,968$ & & & & \\
\hline & Deformed & & & & & & \\
\hline & Artificial & & & & $38,635,968$ & $38,635,968$ & $38,635,968$ \\
\hline
\end{tabular}

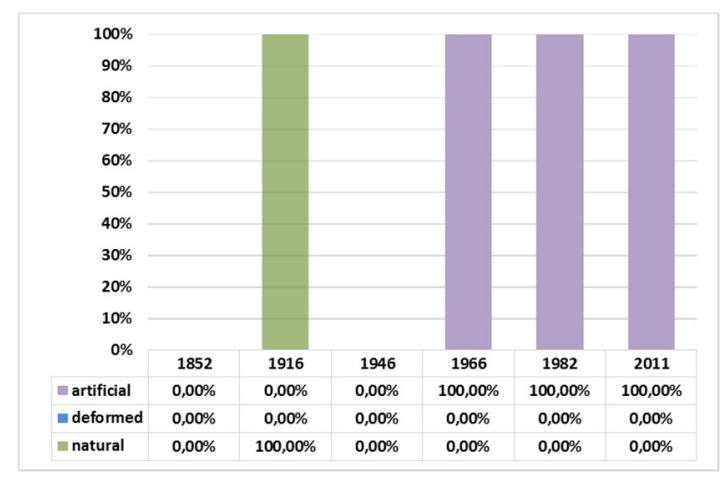

Figure 6: Coastline character distribution in Zone $\mathrm{G}$ by year (\%).

The maps in Fig. 7 have been developed by combining the coastline change analyses year by year. In this summary map, change of Istanbul Bosphorus coastline from 1852 until 2011 can be observed. According to this map, in 1852, the natural coastlines of Bosphorus have started to become deformed as the coasts of the Marmara Sea were preserving their natural state. From the 1918 map, it can be deduced that the northern coasts through Black Sea were also in natural form. It can be witnessed that the deformation on the Bosphorus landscape had started to spread south and north in 1918, while there is no significant change in the Bosphorus area. In 1946, a high percentage of the deformed coastline in the Bosphorus area has been artificialized, and there has been a decrease in the natural coastlines on both southern and northern sides of the Bosphorus. In 1966 the entire Bosphorus line, including the southern parts opening to Marmara Sea, have been artificialized. It can be seen in 1982 and 2011 maps, even though the Bosphorus line and the southern parts opening to Marmara Sea were artificialized, the northern part opening to Black Sea had preserved its natural coastlines. It is conclusive in these results that İstanbul Bosphorus coastlines, which were $1.99 \%$ artificial by 1918 , were $61.39 \%$ artificial in 2011 .

\section{CONCULUSIONS AND DISCUSSION}

The timeline in Fig. 8 provides a chronological order of legislations to compare analysed map's years with the legal coastal regulations in parallel years.

The deformations on natural coastline can be clearly observed on 1852 and 1918 maps. During the Ottoman era where there were not legal regulations for the coast's management. Important changes on coastline character took place between the years 1918 and 1946. Studies show that the artificial coastline had increased from $1.99 \%$ to $30.9 \%$; and in 1966 

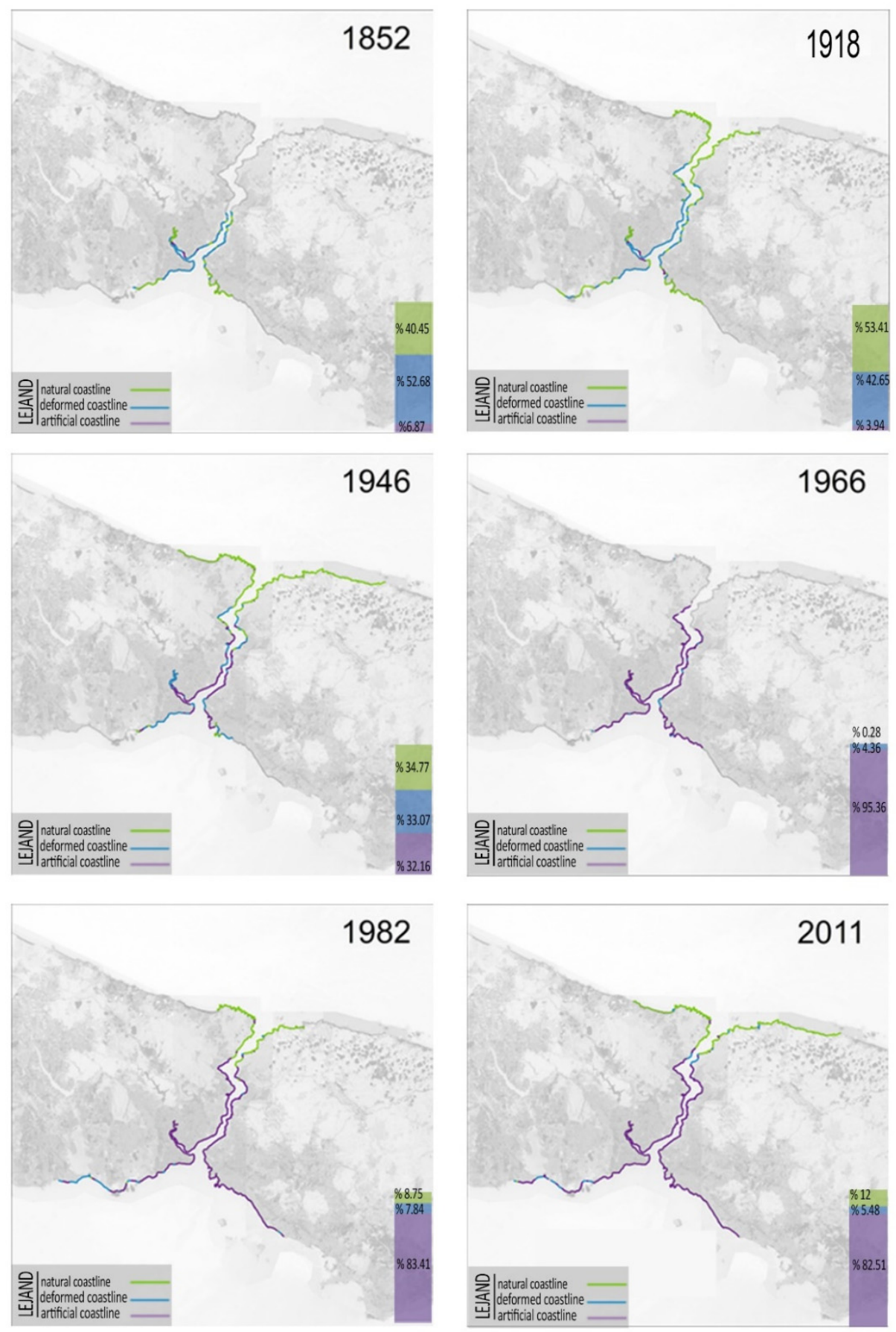

Figure 7: İstanbul coastal characteristics according to the year. 
majority of Bosphorus shores had been converted to artificial coastlines. As seen in Fig. 8, the biggest changes on the Bosphorus coastline had occurred between these years when Civil Law's article 641 and 1961 Constitutions related articles have been enforced. These regulations did not provide any protection for the coastlines, they also didn't focus on the loss of natural characteristics of coasts and related complications with construction planning. Thus, these articles can be considered as indirect causes for the spread of secondary housing on the Bosphorus coastlines and its natural coastline loss caused together with the construction of the transportation infrastructures.

As seen in 1946 and 1982 maps, the effects of urbanization on 1950s and the migrations on 1970s have resulted with the loss in natural features of coastlines. Legal regulations during these periods were Articles 7 and 8 (1972), which provided the legal basis for the fill of coastlines and allowed for private ownership rights in these areas. Later in 1983, Bosphorus Protection Law had been introduced, however in the time of this legislation's implementation, the coastline of the Bosphorus had been completely artificialized. Thus, it

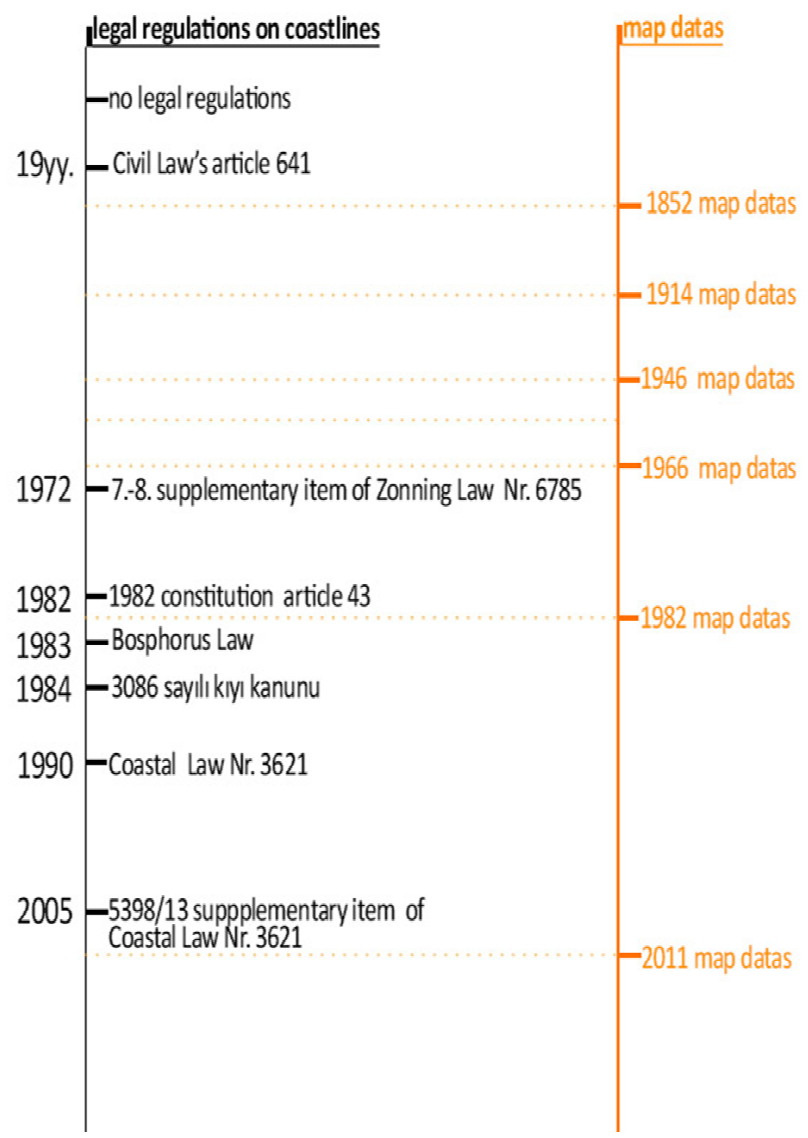

Figure 8: Chronological comparison of costal legal regulations and map data. 
had primarily focused on the existing silhouette of Bosphorus instead of its ecological values. However, by the maps it is clear that Bosphorus coastline had its final shape by 1966, and likewise Eminönü-Avcılar and Kadıköy-Tuzla coastline strip and Haliç had lost its natural state on the same year. Similarly, by the Law No. 3830 in 1992, coastal strip had been defined and taking natural thresholds into consideration, while deciding land use types on coastal parts had been emphasized. But as on the 1882 map data, it is clear that the natural coastline characters in İstanbul's Bosphorus region had already reduced to $25.96 \%$. Thus, it can be thought that this law could not have been effective enough to reveal more ecological decisions on coastline land uses.

Focusing on the 2011 maps, an overall of $61.39 \%$ of natural coastlines are lost in the analyzed area. Depending on these statements, it can be said that, the laws introduced since Ottoman era until Boğaziçi Law could not efficiently enforced ecosystem's protection. Though the change on the natural state of the coastline, is effecting the sub ecosystems and ecosystem services, which have vital importance for the wellbeing of human welfare. $61.39 \%$ coastline character loss for Istanbul indicates; loss on natural systems, deltas, pollution and disappearance of estuary (HALİÇ), as well as losing systems which provide most productive ecosystem services in its natural cycle [7]. Even the Coastline Law in place today does not aim to protect or repair the existing coastal ecosystem values. A comprehensive decisionmaking process on coastal systems must be applied to regulating rules, otherwise the laws itself will go on misleading the coastal land use decisions.

Taking account of the fact that most of the population lives on coastlines, that most efficient ecosystem services are provided by coastlines and that the most endangered ecosystem type is coastal ones, the usage of laws and legislations, as tools for coastline utilization instead of protection, effects the welfare of the populations who benefit from these ecosystems drastically [7].

The outcomes of this study are expected to be used for further research on ecological impact assessment as a result of the loss or degradation of coastal areas.

\section{ACKNOWLEDGEMENTS}

Our thanks to Edin Zaim, who put excellent work into the GIS-analysis part of this research, and to Ecem Duygu Kurangil for her proof-reading service.

\section{REFERENCES}

[1] PAP/RAC, Coastal management in Turkey, Priority Actions Programme Regional Activity Center, Split, 2005.

[2] Döker, F., İstanbul ili Marmara Denizi kıyı: Çizgisinde meydana gelen zamansal değişimin belirlenmesi. International Journal of Human Sciences, 9(2), pp. 1350-1370, 2012.

[3] Karaburun, A. \& Demirci, A., The changing risks of agricultural activities on water resources in rapidly urbanized areas: Agricultural land cover change in Istanbul between 1987 and 2007. Fresenius Environmental Bulletin, 18(11a), pp. 2181-2191, 2009.

[4] Karaburun, A., Demirci, A., \& I-Shian, S., Impacts of urban growth on forest cover in Istanbul (1987-2007). Environmental Monitoring and Assessment, 166(1), pp. 266-277.

[5] Tezer, A., Modeling of land use-transportation interaction in Istanbul. ITU $A \mid Z, \mathbf{1}(2)$, pp. 12-25, 2010.

[6] Duru, B., Kıyı politikası, Mülkiyetler Birliği, Vakfı Yayınları Tezler Dizisi, 13, 2003.

[7] Millenium Ecosystem Assessment (MEA), Ecosystems and Human Wellbeing, Synthesis, Island Press: Washington, DC, 2005. 